\title{
Implementation of Islamic Character Values in Online Learning of Literature
}

\author{
Turahmat \\ Universitas Islam Sultan Agung, Semarang, Indonesia
}

\{lintangsastra@unissula.ac.id\}

\begin{abstract}
In 2020, Covid-19 outbreak hit around the world. In Indonesia, the first case tested positive for Covid-19 was found on March 2, 2020. Furthermore, the government gradually imposed territorial quarantine. In education realm, system of studying from home started since March 2020. Lecturers and students had have virtual interaction through available learning application. Problems arised along with online learning system, such as the lack of supporting facilities and equipments, the lack of lecturers' competence, the unpreparedness by lecturers and students, and the lack of characteristics of online learning. This study focused on the lack of chracteristics in online learning, which was only to deliver cognitive aspects but but it is difficult to get used to the implementation of character values. Thus, the issue that will be reviewed in this study is 'how is the implementation of Islamic character values in online learning for students in Indonesian Language and Literature Education Study Program?
\end{abstract}

keywords: islamic character, online learning of literature

\section{Introduction}

Indonesia announced the first Covid-19 case on March 2, 2020. After that, the confirmed cases increased in high numbers. Covid-19 is a highly contagious disease. The disease is caused by Coronavirus that especially attacks human respiratory system [1]. The suspect who failed to resist on the disease would lead to death. Indonesia government had conducted various efforts to handle this horrible epidemic. In education, Government as represented by High Education Directorate of Education and Culture Ministry issued a decree No. 1 in 2020 about Prevention of Corona Virus Disease (Covid-19) Spreading in University. The decree regulated, one of them, about conducting virtual learning based on condition of each university, and suggested that students to conduct studying from home within online learning [2].

The decree is the legal regulation that prevents face-to-face learning temporarily. Students had online learning from their own home. This activity is due to physical distancing matter. The physical distancing implemented in order to reduce physical contact that potentially leads to disease contagion is then called as social distancing [3]. The social distancing is implemented in order to curb the spread of Covid-19. Stein suggested that social distancing is required to curb the spreading of Covid-19 [4]. In the first weeks of online learning from 
home, most of students and lecturers felt somewhat disconnected with this kind of system. Some of them issued many complains on this online learning. Some lecturers even gave some assignments as replacement for online meeting. Many students complained about high numbers of assignments they got to hand in. Purpose of learning for weeks did not meet the expectation. A stagnation was inevitable in learning process.

Online learning had various minors, such as the availability of supporting equipments, the internet network, and also characteristics in learning system. The online learning should be conducted by using digital technology so students and lecturer could be in different places during the learning [5]. This kind of virtual interaction in learning is still rare in Indonesia. The supporting facilities for this online learning were still not enough. On the other hand, online learning requires supporting mobile tools such as smartphones, tablets, and laptops to access information anywhere and anytime [6]. Laptop and smartphones are used by students to access information through internet in learning through video conference, virtual classes, and other online learning applications [7]; [8]; [9]; [10]). Both students and lecturer should have supporting tool for online learning. The tools are used to access internet through mobile technology [11]. The usage of mobile technology had huge contribution in education, such as in accomplishing goals of distance learning. However, in fact, this mobile technology could be used to deliver purpose of learning on its cognitive aspect only. The psycho-motoric aspect in literary learning could not be delivered optimally. Also, the affective aspect could not meet its goals as expected.

Limitations in online learning has raised new issues. The first was that students had more intense activities on internet. On the other hand, we all know that internet could lead students to freely access any information. Unfortunately, too many negative information on internet. Not all students had enough intelligence to filter bad informations. It could lead to anxiety of negative impacts caused by the usage of gadget and social media, such as the possibility of wrong information influence and unawareness during the learning for surfing on social media [12]. Besides, those who have gadget addiction seemed to have social and academic issues [13]. Another problem arised as the limitations of online learning was that; how to deliver character values in online learning. Education should be interpreted as a process of transforming individual's character into better being. Education not only transforms a person into a smart, clever, and intelligent person, but also into a person that was better, honest, well mannered, more faithful and had other good values as concerned in character education. Values in characters are various. One of them is islamic character.

Islamic character values are values of goodness as referred from Islamic teaching values. Those islamic values are obtained from the Holy Qor'an and Al-Hadits. Description of islamic character values could be very vast, as the teachings in Islam would automatically become Islamic character values. Thus, previous studies and especially this study would be difficult to define islamic character values in detail. To solve the difficulty, it is helpful to take general definition as described in the beginning of this paragraph. Islamic character values as one of virtues should be values to deliver to students, especially in Sultan Agung Islamic University (Unissula). This Islamic values would lead student to become better in the upcoming future. All students should absorb values of Islamic characters internalised by the lecturers through subjects. When learning became online, how could islamic character values be implemented? Interaction in online learning had limitations so it is impossible for lecturers to directly watch students' activities during the learning [14]. This article would describe and discuss the problem. 


\section{Research Method}

This study was conducted by library research method. Libary research is a kind of study that reviews various references and typical previous studies to obtain theoretical basis for the problem studied [15]. It should be distinguished between literature as an independent research methodology and literature as one of the steps in a study. In research by any method, literature studies will always be the first step in putting together a foundation of thinking. In this article, literature is meaningful as an independent research method. This method was used as the problem of the study could only be solve by using library research and field research methods [16]. Library research methods will not be found in qualitative studies. This method then became rare to the researchers of the exact science field. In the fields of historical, social, humanities, and literature, this method of research is no stranger. So this article can also be a reference for the researchers of a field, also become a new knowledge for the researchers of the field of exact science. This research method is used to develop concepts about the application of Islamic character values in online literary learning. Gradually this concept is being applied in classes that are being enabled by researchers.

\section{Result and Discussion}

Online learning is a model of learning that has been known for a long time in Indonesia. However, its implementation has not been implemented massively. The world of education, industry, and all aspects of life in Indonesia, prior to covid-19, is preparing for the industrial revolution 4.0. The change towards the era of industrial revolution 4.0 had to go so fast because it was "forced" by the rise of Covid-19. So for us, Indonesians, this Covid-19 outbreak provides an important lesson that rapid and massive change is taking place in all aspects of life, in all parts of the world. And we have to be prepared to go with the flow of those changes if we don't want to miss out. So the researchers came to a new realization that life must continue, that education must continue, and the values of Islamic character must still be conveyed. Then the things that can be done to start the effort are as follows..

\subsection{Planning in Online Learning by Including Islamic Character Values}

Planning in online learning is very decisive point of success or not a learning. Often the online learning process does not achieve maximum results because it does not start from good learning planning. Through this learning plan, lecturers can determine the best learning scenarios, determine the type of online learning application to be used, plan the allocation of time appropriately, and formulate the type of evaluation to be used. Through this learning plan, Islamic character values must be planned to be integrated into the learning. Online learning is a learning that uses an internet network with accessibility, connectivity, flexibility, and the ability to bring forth different types of learning interactions [17]. Thus, an online learning plan must also be drawn up to meet these characteristics.

Online learning planning will make the learning process run more regularly so that it is easier for lecturers to integrate the values of Islamic character. Lecturers become easier in providing literary materials to students, so that learning targets can be achieved because it has been planned in such a way in the beginning before learning occurs. With good planning, every element in the learning process that includes lecturers and students is able to understand its role well in the learning process because the tasks they should be working on have been 
planned in advance. Because this learning has been run within the plot stipulated in a careful planning by lecturers, then the application of Islamic character values could run well. The unsuccessfulness of online learning often happened as the lecturers did not plan well. The unprepared lecturer met the students in virtual room could just conduct improvisation in the learning process. Online learning should provide new experience for both students and lecturer. Zhang et al. [18] indicated that the usage of internet and multimedia technology could construct options of knowledge delivery and could be an alternative for learning in traditional class.

Islamic character values will be well integrated into online literary learning if they have been carefully prepared in learning planning. Through this learning plan, lecturers can prepare the value of Islamic character which will be integrated in the learning process. In drama staging courses for example, lecturers must make careful planning in order to integrate the values of Islamic character in it. If no learning planning is done, then it is impossible for lecturers to incorporate the values of this Islamic character into the learning process.

\subsection{Selection of Suitable Application for Online Learning}

Selecting application or media for online learning should be adjusted to characteristic of materials delivered. One of supporting media to succeed the online learning is social media. Lau suggested that social media had entered the life of younger adult [19]. It means that social media is not only used by youngsters, but also by adults. The adults in Indonesia, mostly under 55 years old, had used social media too. Lecturers are included into a category of profession that get used to use scial media [20]. Online learning could be even conducted through social media such as Facebook and Instagram. Thus, the lecturers could use social media as a facility for online learning to include Islamic character values.

Poem Writing subject in Unissula is one of examples of subject that could use social media as tool for online learning. In this subject, students are required to have competence in creating a poem within certain rules contained Islamic character values. The lecturer could use Facebook or Instagram as media of publication for their poems. Only those who had good poems and contained Islamic character values will be posted on the lecturer's own Facebook or Instagram accounts. The one whose poem was posted on the lecturer's social media would receive comments from both the lecturer and fellows. Of course his fellows were previously told to provide good comment. It could raise pride for the student. The ones whose poems were not posted by the lecturer could be triggered or motivated to be better in the upcoming occasion.

On the Literary Theory subject, the lecturer could use social media as tool for online learning. Students are accustomed to using social media as a medium of interaction [21]. Students use social media to express themselves, their opinion, and make friends. Students' habits as a medium of interaction and self-expression can be utilized by lecturers in the study of Literary Theory. Students are told to express themselves in the form of more meaningful short stories. Students will create short stories using a diction that is literary as well as charged with the value of Islamic characters. After that, the student was told to upload his work on his Facebook account. Lecturers make meaningful comments on the work of students. Comments submitted by lecturers contained positive motivation and did not make them down.

Two examples above could be impossibly done if the learning media is not Facebook or Instagram. The examples could be used in other media such as virtual class by Zoom. The lecturer had such intuition to choose various online learning media based on characteristics of the materials. Other media also could be used to support the online learning, such as virtual 
classes through Google Classroom [22]; [23]; [24]), and instant messaging applications such as WhatsApp [25].

Online learning media, which is often used in lectures, is generally grouped into two, namely; text-based learning media and audio visual-based learning media. Text-based learning media is defined as an online learning medium that uses only text as a means of learning. Audio visual-based learning media is an online learning medium capable of displaying audio and visuals simultaneously or alternately, with pole interactions one time or different times. Examples of text-based learning media are facebook, instagram, google classroom, edmodo. Examples of audio visual-based learning media are zoom, google meet, google teams, and other media that can be used for virtual face-to-face. Each of these online learning media has distinctive and unique characteristics. Lecturers will experience a failure in online learning if they choose the right media. The selection of media in accordance with the characteristics of the material to be conveyed, greatly determines the values of the character of Islam that will be integrated in the learning process.

\subsection{Managing Islamic Interaction Pattern}

Main purpose of education is to transform human into a better one. It is in line with Umamah suggesting that life skills and character building is a way to contribute each other in character bulding, as the main purpose of learning activity is to provide guidance and service to students in order to transform them into an educated person [26]. The shift in the learning paradigm from offline systems to online systems should not deflect the direction of actual educational goals. The purpose of education must remain in the proper nature of changing people for the better. Online learning emphasizes a new value that used to be difficult to achieve with offline learning systems, such as self-reliance and responsibility. Kuo et al. [27] indicated that online learning is more student-centered, so it could develop students' responsibility and autonomy in learning. Students learn to become independent in the online learning process. The limitations of direct interaction space, both with lecturers and with friends, make students learn to be more independent. In line with this self-reliance, students are also learning to be more responsible. This behavior appears to be in the accuracy of the lectures and the timeliness of the task collection. Online learning also requires students to always be agile when there is a very sudden change in the lecture system. For example, lectures that should be scheduled to use zoom because the internet network is difficult, then have to be replaced with other applications such as Edmodo. This sudden change trains students to be adaptive and responsive to change.

Self-reliance and responsibility are more difficult to implement if using an offline learning system. On the other hand, values that are relatively easy to apply when learning offline, become difficult to apply with online learning systems, such as honesty and decency values. Therefore, a breakthrough was needed in unraveling the difficulty of planting the values of the character, including the application of Islamic values. One of the efforts that can be made is to improve the pattern of interaction between lecturers and students. Lecturer in Indonesian philosophy is a person who is able to set an example for his students, his soul is filled with patience and compassion in educating. Lecturers not only teach but also educate. Lecturers become role models for their students. Thus, interaction with lecturers is important as it could reduce psychological distance that leads to a better learning [28].

The pattern of interaction that lecturers must practice in online learning to instill the value of Islamic character is an Islamic pattern of interaction. Islamic interaction patterns are patterns of interaction that prioritize compassion. The lecturer must instill in his heart that the 
student is a creature of God who is a trust that must be properly educated. On a technical level, the pattern of interaction that can be practiced for example is as follows. Say hello before starting an online lecture. Reciting prayer in the beginning of the learning. Motivating students at the beginning of online lectures. Using familiar greetings. Delivering one specific value taken from the Qor'an or Al Hadith. Don't scold students. The lecturer should also be able to conduct his main functions in character education as agent of learning including as a role model, inspirator, motivator, dynamicator, and evaluator [29].

The pattern of good interaction between lecturers and students is strongly influenced by their respective personality backgrounds. In the online learning process, who is in control of the entire learning process is the lecturer. Then lecturers must give an example first, the pattern of interacting Islamicly. If any student is in the naughty category, like to make a mistake in class, or it's hard to tell and be directed. So lecturers should not directly scold the student. Lecturers should reconsider the philosophical meaning of Islamic teachings, i.e. must be self-introspective. Don't let the lecturer ever hurt students or mistreat them before. If that is not the case, lecturers must also follow the teachings of the Prophet Muhammad, which is to pray for the student to be good. The dimension of prayer is a immaterial dimension that is rarely discussed in the world of science and research because it does not meet scientific aspects and rules. But the value of Islamic character in the pattern of interaction, places prayer on the most important element of the whole element that exists.

\title{
3.4 Integrating Islamic Character Values in Literary Material
}

The last part of islamic character values implementation in literary learning is by integrating the material. Organizing course materials is one of competences that shuold be owned by the lecturer. A good organization of materials leads to a good classroom management [30]. Integrating islamic character values in literary materials could be divided into two parts. The first part is the lecturer should find a verse in he Holy Quran as phylosophical basis for the literary materials. For example, in Poem Writing subject. There is a verse in the Quran telling about poets; QS. Ash-Shura verse 224-227 saying that: "And the poets - [only] the deviators follow them; Do you not see that in every valley they roam and that they say what they do not do? Except those [poets] who believe and do righteous deeds and remember Allah often and defend [the Muslims] after they were wronged. And those who have wronged are going to know to what [kind of] return they will be returned."

Meaning of these verses are that poets are those who are not righteous and deviant from truth, except those who always praises the Almighty Allah SWT in their poems [31]. The lecturer should tell the students to write poems well in order to praise Allah SWT, not to write a poem that potentially could keep people away from Allah. The lecturers should have this kind of competence in order to integrate islamic values to learning materials. The second part is that the lecturer displayed examples of literary works containing islamic values. This is an alternative for the lecturers who could not use the first part to integrate islamic character values in literary materials. For example, in Poem Writing subject, the lecturer should provide a poem containing islamic character values, such as a poem below.

\author{
Puisi Islam \\ (A Poem of Islam) \\ by: KH A Mustofa Bisri
}

Islam agamaku nomor satu di dunia 
Islam benderaku berkibar di mana-mana

Islam tempat ibadahku mewah bagai istana

Islam tempat sekolahku tak kalah dengan yang lainnya

Islam sorbanku

Islam sajadahku

Islam kitabku

Islam podiumku kelas exclussive yang mengubah cara dunia memandangku

Tempat aku menusuk kanan kiri

Islam media massaku

Gaya komunikasi islami masa kini

Tempat aku menikam sana sini

Islam organisasiku

Islam perusahaanku

Islam yayasanku

Islam istansiku, menara dengan seribu pengeras suara

Islam muktamarku, forum hiruk pikuk tiada tara

Islam bursaku

Islam warungku hanya menjual makanan sorgawi

Islam supermarketku melayani segala keperluan manusiawi

Islam makananku

Islam teaterku menampilkan karakter-karakter suci

Islam festifalku memeriahkan hari-hari mati

Islam kaosku

Islam pentasku

Islam seminarku, membahas semua

Islam upacaraku, menyambut segala

Islam puisiku, menyanyikan apa saja

Tuhan Islamkah aku?

A poem by Gus Mus entitled "Puisi Islam" is an example of a poem that contains islamic character values. The poem indicated islamic characters as viewed from its typography and physycal and mental elements. The lecturer could provide other literary works that contain Islamic character values to students. The lecturer could give assignment to the students to create a poem with islamic character values. 


\section{Conclusion}

The shift of the learning paradigm from offline systems into online systems demands that we be more responsive and adaptive in the face of the various changes that occur. Changes in the learning system should not change the purpose of education that is to change people for the better. This change can be made one of them by incorporating the value of Islamic characters in the process of online literary learning. Efforts can be made to achieve these goals there are four: planning online learning by including the value of Islamic characters, the selection of suitable online learning application, regulating the pattern of Islamic interaction, and integrating the value of Islamic character in literary material. If these four things can be done comprehensively, then the integration of Islamic character values in online literary learning can still be implemented.

\section{References}

[1] Rothan, H. A., \& Byrareddy, S. N.: The epidemiology and pathogenesis of coronavirus disease (COVID-19) outbreak. Journal of Autoimmunity. https://doi.org/10.1016/j.jaut.2020.102433 (2020).

[2] Direktorat Jenderal Pendidikan Tinggi Kementerian Pendidikan dan Kebudayaan: Surat Edaran Nomor 1 Tahun Tentang Pencegahan Penyebaran Corona Virus Disease (Covid-19) Di Perguruan Tinggi. Kementerian Pendidikan dan Kebudayaan (2020).

[3] Bell, D., Nicoll, A., Fukuda, K., Horby, P., Monto, A., Hayden, F., ... Van Tam, J.: Nonpharmaceutical interventions for pandemic influenza, national and community measures. Emerging Infectious Diseases. https://doi.org/10.3201/eid1201.051371 (2006).

[4] Stein, R.: COVID-19 and Rationally Layered Social Distancing . International Journal of Clinical Practice. https://doi.org/10.1111/ijcp.13501 (2020).

[5] Milman, N. B. Distance Education: In International Encyclopedia of the Social \& Behavioral Sciences: Second Edition. https://doi.org/10.1016/B978-0-08-0970868.92001-4 (2015).

[6] Gikas, J., \& Grant, M. M.: Mobile computing devices in higher education: Student perspectives on learning with cellphones, smartphones \& social media. Internet and Higher Education. https://doi.org/10.1016/j.iheduc.2013.06.002 (2013).

[7] Kay, R. H., \& Lauricella, S.: Exploring the Benefits and Challenges of Using Laptop Computers in Higher Education Classrooms: A Formative Analysis. Canadian Journal of Learning and Technology / La Revue Canadienne de l'apprentissage et de La Technologie. https://doi.org/10.21432/t2s598 (2011).

[8] Gikas, J., \& Grant, M. M. Mobile computing devices in higher education: Student perspectives on learning with cellphones, smartphones \& social media. Internet and Higher Education. https://doi.org/10.1016/j.iheduc.2013.06.002 (2013).

[9] Chan, N. N., Walker, C., \& Gleaves, A.: An exploration of students' lived experiences of using smartphones in diverse learning contexts using a hermeneutic phenomenological approach. Computers and Education. https://doi.org/10.1016/j.compedu.2014.11.001 (2015).

[10] Gökçearslan, Ş., Mumcu, F. K., Haşlaman, T., \& Çevik, Y. D.: Modelling smartphone addiction: The role of smartphone usage, self-regulation, general self-efficacy and 
cyberloafing in university students. Computers in Human Behavior. https://doi.org/10.1016/j.chb.2016.05.091 (2016).

[11] Korucu, A. T., \& Alkan, A.: Differences between m-learning (mobile learning) and elearning, basic terminology and usage of m-learning in education. Procedia - Social and Behavioral Sciences. https://doi.org/10.1016/j.sbspro.2011.04.029 (2011).

[12] Siddiqui, S., \& Singh, T.: Social Media its Impact with Positive and Negative Aspects. International Journal of Computer Applications Technology and Research. https://doi.org/10.7753/ijcatr0502.1006 (2016).

[13] Kwon, M., Lee, J. Y., Won, W. Y., Park, J. W., Min, J. A., Hahn, C., ... Kim, D. J.: Development and Validation of a Smartphone Addiction Scale (SAS). PLoS ONE. https://doi.org/10.1371/journal.pone.0056936 (2013).

[14] Firman, Sari Rahayu Rahman. Pembelajaran Online di Tengah Pandemi Covid-19. Indonesian Journal of Educational Science (IJES). Volume 02, No 02 Maret 2020. P 81-89. ISSN 2622-6197 (online) ISSN 2655-4402 (Cetak).

[15] Jonathan, Sarwono: Metode Penelitian Kuantitatif dan Kualitatif. Yogyakarta: Graha Ilmu (2006).

[16] Zed, Mestika: Metode peneletian kepustakaan. Jakarta: Yayasan Obor Indonesia (2008).

[17] Moore, J. L., Dickson-Deane, C., \& Galyen, K.: E-Learning, online learning, and distance learning environments: Are they the same? Internet and Higher Education. https://doi.org/10.1016/j.iheduc.2010.10.001 (2011).

[18] Zhang, D., Zhao, J. L., Zhou, L., \& Nunamaker, J. F.: Can e-learning replace classroom learning? Communications of the ACM. https://doi.org/10.1145/986213.986216 (2004).

[19] Lau, W. W. F.: Effects of social media usage and social media multitasking on the academic performance of university students. Computers in Human Behavior. https://doi.org/10.1016/j.chb.2016.11.043 (2017).

[20] Kumar, V., \& Nanda, P.: Social Media in Higher Education. International Journal of Information and Communication Technology Education. https://doi.org/10.4018/ijicte.2019010107 (2018).

[21] Kim, Y., Wang, Y., \& Oh, J.: Digital Media Use and Social Engagement: How Social Media and Smartphone Use Influence Social Activities of College Students. Cyberpsychology, Behavior, and Social Networking. https://doi.org/10.1089/cyber.2015.0408 (2016).

[22] Enriquez, M. A. S.: Students 'Perceptions on the Effectiveness of the Use of Edmodo as a Supplementary Tool for Learning. DLSU Research Congress. https://doi.org/10.1017/CBO9781107415324.004 (2014).

[23] Sicat, A. S.: Enhancing College Students' Proficiency in Business Writing Via Schoology. International Journal of Education and Research. Vol. 3 No. 1 January 2015. P 159-178. ISSN: 2201-6333 (Print) ISSN: 2201-6740 (Online) (2015).

[24] Iftakhar, S.: GOOGLE CLASSROOM: WHAT WORKS AND HOW? Journal of Education and Social Sciences. Vol. 3, (Feb. 2016). P 12-18. ISSN 2289-9855 (2016).

[25] So, S.: Mobile instant messaging support for teaching and learning in higher education. Internet and Higher Education. https://doi.org/10.1016/j.iheduc.2016.06.001 (2016).

[26] Umamah, Z.: Internalisasi Life Skills dalam Pembelajaran: Studi Atas Penguatan Pendidikan Karakter di MIN 1 Kota Madiun. Jurnal Tarbiyatuna, 9 (2) (2018). 
[27] Kuo, Y. C., Walker, A. E., Schroder, K. E. E., \& Belland, B. R.: Interaction, Internet self-efficacy, and self-regulated learning as predictors of student satisfaction in online education courses. Internet and Higher Education. https://doi.org/10.1016/j.iheduc.2013.10.001 (2014).

[28] Swan, K.: Building Learning Communities in Online Courses: the importance of interaction. Education, Communication \& Information. https://doi.org/10.1080/1463631022000005016 (2002).

[29] Mulyasa: Menjadi Guru Profesional; Menciptakan Pembelajaran Kreatif dan Menyenangkan, Bandung: PT Remaja Rosdakarya, (2008).

[30] Purnomo, Halim; Firman Mansir; Tumin; dan Suliswiyadi: Pendidikan Karakter Islami pada Online Class Management di SMA Muhammadiyah 7 Yogyakarta Selama Pandemi Covid-19. Jurnal Tarbiyatuna Vol. 11 No. 1. pp. 91-100. pISSN: 2085-0889. eISSN: 2579-4981 (2020).

[31] Syihab, M. Quraish: Tasfir Al Misbah. Lentera Hati: Tangerang (2005). 